\title{
Home-range analyses and habitat use by white-tailed deer females during the breeding season
}

\author{
Alejandra Soto-Werschitz ${ }^{1,3 *}$, Salvador Mandujano² and Sonia Gallina Tessaro² \\ ${ }^{1}$ Posgrado, Instituto de Ecología A. C. Antigua Carretera a Coatepec 351, El Haya CP. 91070, Xalapa. Veracruz, México. Email: \\ alewerschitz@gmail.com (ASW). \\ ${ }^{2}$ Red de Biología y Conservación de Vertebrados Instituto de Ecología A. C. Antigua Carretera a Coatepec 351, El Haya CP. 91070, \\ Xalapa. Veracruz, México. Email: salvador.mandujano@inecol.mx (SMR), sonia.gallina@inecol.mx (SGT). \\ ${ }^{3}$ Laboratorio de Zoología Aplicada, Departamento de Biología, Facultad de Ciencias, Universidad de Los Andes, Núcleo La \\ Hechicera, Mérida CP. 5101, Mérida, Venezuela. \\ *Corresponding author
}

\begin{abstract}
There is little knowledge about the behavior strategies used by white-tailed deer (Odocoileus virginianus texanus) females with fawns. This study analyzed the variation in home range and the use of vegetation types by eight females during the breeding season in a brushland in northeastern Mexico and compared the strategies of females with and without fawns. Eight females were captured and radiotelemetry collars were fitted to them. We sampled two to three 24-hour cycles at 1-hour intervals monthly from April to October 1997 and 1998. In 1997 all females had fawns, whereas in 1998 some of these females had no fawns. This allowed comparing the strategies of females with and without offspring. The home range was significantly larger in females with fawns. In particular, no monthly variations in the home range were observed when females had fawns, while the home range was larger in August in females without fawns. Females preferred two of the seven habitat types (plant associations) studied, the ones dominated by Acacia-Prosopis and by Leucophyllum frutescens. Monthly variations were noted in both home-range size and use of plant associations when females were raising fawns. These data allow a better understanding of the behavioral strategies of females, which may contribute to the development of management strategies.
\end{abstract}

Se conoce poco acerca de las estrategias conductuales que emplean las hembras de venado cola blanca Odocoileus virginianus texanus con crías. En este estudio se analizó la variación del tamaño de ámbito hogareño y el uso de asociaciones vegetales de hembras durante la época de crianza en un matorral xerófilo del noreste de México y se hicieron comparaciones entre hembras con y sin crías. Se utilizó la técnica de radiotelemetría para registrar los movimientos de ocho hembras capturadas, realizando dos a tres ciclos de 24 horas (localizaciones cada hora), mensuales de abril a octubre de 1997 y 1998. Además se comparó el comportamiento entre hembras con crías (1997) y hembras sin crías (1998). El ámbito hogareño fue significativamente mayor en las hembras con crías. No hubo variación mensual en el ámbito hogareño cuando las hembras tuvieron crías, mientras que en el mes de agosto el ámbito fue mayor en las hembras sin crías. De las siete asociaciones vegetales, todas las hembras tuvieron preferencias por dos, las dominadas por Acacia-Prosopis y Leucophyllum frutescens. Se observó variación mensual en el tamaño del ámbito hogareño y en el uso de las asociaciones vegetales cuando las hembras de venado cola blanca están criando. Estos datos permiten conocer mejor las estrategias exitosas de reclutamiento de nuevos individuos a las poblaciones de venados, lo cual puede ayudar a desarrollar estrategias de manejo.

Key words: activity patterns; Nuevo León; Odocoileus virginianus; radiotelemetry.

๑ 2018 Asociación Mexicana de Mastozoología, www.mastozoologiamexicana.org

\section{Introduction}

Females of the white-tailed deer Odocoileus virginianus (Zimmermann 1780) display complex behavioral patterns during pregnancy, birth and breeding, probably aimed at maximizing offspring survival (Kie and White 1985; Wallace 1990; Wallace and Krausman 1990; Schwede et al. 1993). Breeding fawns is likely to modify the type of areas used by females, as well as foraging and anti-predator strategies, and social responses (Gilliam and Fraser 1987; 1989; Holzenbein and Schwede 1989; Schwede et al. 1994; Main et al. 1996; Bowyer et al. 1998; Bongi et al. 2008; DeYoung and Miller 2011). It is generally accepted that parturition induces a temporary reduction in home-range size, habitat use, and social interactions (Nelson and Mech 1981; Ozoga et al. 1982; Holzenbein and Schwede 1989; Nixon et al. 1992; Zultowski 1992; Schwede et al. 1993; Fox and Krausman 1994). The only published study comparing female deer with and without fawns found no differences in homerange size (Bertrand et al. 1996).

In northeastern Mexico, a number of studies have compared the behavior of males and females of the subspecies O. v. texanus (Gallina et al. 2003), by analyzing the use of habitat between years, sexes and reproductive periods (Bello et al. 2001a, 2003), home range (Bello et al. 2001b), movements in relation to precipitation (Bello et al. 2004), distances traveled (Bello et al. 2006), energy expenditure (Gallina and Bello 2010), and activity (Gallina and Bello 2014). The current knowledge about pregnancy and fawning is limited. It is considered that home-range size and habitat use directly influence the deer population dynamics (Gallina 1981; Gallina et al. 1998; Green et al. 2017), reproductive patterns (gestation, number of offspring, time of parturition, fawn survival, size of mothers and fawns), and the behavior of mothers (Green et al. 2017). The objective 
of this study was to determine the behavioral strategies of females of white-tailed deer with and without fawns under conditions of semi-captivity, estimating home-range size and use of plant associations in a brushland.

\section{Materials and Methods}

Study Area. This work was carried out at Rancho San Francisco, located between the municipalities of Lampazos and Progreso in the States of Nuevo León and Coahuila $\left(27^{\circ} 22^{\prime}\right.$ $\mathrm{N},-100^{\circ} 40^{\prime} \mathrm{W} ; 27^{\circ} 22^{\prime} \mathrm{N},-100^{\circ} 36^{\prime} \mathrm{W} ; 27^{\circ} 20^{\prime} \mathrm{N},-100^{\circ} 40^{\prime} \mathrm{W}$; $\left.27^{\circ} 20^{\prime} \mathrm{N},-100^{\circ} 36^{\prime} \mathrm{W}\right)$. The study area stretches across 1,500 ha, including a 1,000 ha enclosed in a deer fence, with 33 artificial 1500-L water troughs in addition to three dams whose water level depends entirely on rainfall (Bello et al. 2001a). Maximum temperature can reach $40{ }^{\circ} \mathrm{C}$, and the maximum mean temperature in July reaches only $29^{\circ} \mathrm{C}$ (Briones 1984). The climate is warm and dry, with mean annual precipitation below $400 \mathrm{~mm}$; the rainy season spans from May to September, showing interannual variations (Bello et al. 2001a; Bello et al. 2004). The estimated deer density is 8 to 10 individuals per $\mathrm{km}^{2}$, and between 80 and 100 deers are estimated to thrive in the area (Gallina and Bello 2010; Bello et al. 2001b).

The local vegetation is a xeric scrubland, including seven plant associations with variable cover: $1 \%$ medium-height thorny mezquite-acacia brushland, $3 \%$ toboso grassland (Hilaria mutica $=$ Pleuraphis mutica), $6 \%$ thornless hojasen shrubland (Flourensia cernua), $10 \%$ chaparro prieto (Acacia-Celtis), $11 \%$ cenizo shrubland (Leucophyllum frutescen), $15 \%$ high thorny mezquite-acacia shrubland (Prosopis), and 54\% medium sub-thorny mezquite-acacia-toboso-hojasen shrubland (Acacia-Prosopis; Bello et al. 2001b). Factors considered were availability of each association, species richness, cover protection and percent of food species in each association.

Although the predation of adult females and fawns was not documented in this study, the presence of puma (Puma concolor), bobcat (Lynx rufus), feral dog (Canis lupus familiaris) and coyote (Canis latrans) was recorded in the study area, all being potential predators (Cook et al. 1971; Ozoga and Verme 1982; Messier and Barrette 1985). Breeding coyote couples predate on deer fawns, mostly during July and August (Lopez-Soto and Badii 2000).

Capture and Radio Tracking. Females were captured using a $15 \times 15 \mathrm{~m}$ drop net with a $20 \mathrm{~cm}$ mesh modified for capturing deer, with a manual trigger that is activated from a distance of approximately $30 \mathrm{~m}$. Corn grains were used as bait. When a deer was captured, eyes were covered (to keep it calm); then it was untangled from the net and the legs were tied to facilitate handling. This procedure is commonly used in the UMAS located in the States of Nuevo León, Coahuila and Tamaulipas. Each deer was weighed with a Pesola $100 \mathrm{~kg}$ dynamometer and was fitted with a $180 \mathrm{~g}$ radio transmitter collar with activity sensor (Model 400, Telonics, Inc. Meza, Arizona). No anesthetic were administered to avoid complications in deer handling (Bello et al. 2001a).

Eight females were captured, six in 1997 and two in 1998 (Table 1). Three were captured within the 1,000 ha confinement area, and five outside of this area. The six females monitored in 1997 were raising fawns. The six females monitored in 1998 had no fawns.

Table 1. Year of capture and number of monthly locations of females of Texan white-tailed deer in Rancho San Francisco, Nuevo León.

\begin{tabular}{|c|c|c|c|c|c|c|c|c|c|c|c|}
\hline \multirow[t]{2}{*}{ Female } & \multirow{2}{*}{$\begin{array}{l}\text { Year } \\
\text { of } \\
\text { capture }\end{array}$} & \multicolumn{5}{|c|}{$\begin{array}{l}\text { Number of locations } \\
\text { with fawns }\end{array}$} & \multicolumn{5}{|c|}{$\begin{array}{l}\text { Number of locations } \\
\text { without fawns }\end{array}$} \\
\hline & & Apr & Jun & Aug & Oct & Total & May & Jun & Aug & Oct & Total \\
\hline 1 & 1997 & 14 & 29 & 45 & 31 & 119 & 46 & 30 & 41 & 28 & 145 \\
\hline 2 & 1997 & 10 & 20 & 12 & 33 & 75 & 36 & 21 & 33 & 25 & 126 \\
\hline 3 & 1997 & 16 & 35 & 38 & 30 & 119 & 47 & 41 & 43 & 30 & 161 \\
\hline 4 & 1997 & - & 30 & 52 & 30 & 112 & 30 & - & 25 & 25 & 80 \\
\hline 5 & 1997 & 42 & 19 & 20 & 19 & 100 & - & - & - & - & - \\
\hline 6 & 1997 & - & - & 56 & - & 56 & - & - & - & - & - \\
\hline 7 & 1998 & - & - & - & - & - & 33 & 15 & 14 & 34 & 96 \\
\hline \multirow[t]{2}{*}{8} & 1998 & - & - & - & - & - & 18 & - & 17 & 13 & 48 \\
\hline & Total & 82 & 133 & 223 & 143 & 581 & 240 & 107 & 209 & 180 & 736 \\
\hline
\end{tabular}

All the females studied were located using radio telemetry (White and Garrot, 1990). Female locations were recorded in May, July, August and October 1997, and in April, July, August and October 1998, corresponding to the breeding season (Table 1). Data were obtained at 1-h intervals, performing two to three 24 hour cycles each month. Each deer specimen was radio-located by triangulation using TR2 and TR4 receptors (Telonics Inc., Meza, Arizona;) and $\mathrm{H}$ - and Yaguis-type portable antennas (Telonics Inc., Meza, Arizona) from two or three fixed stations (Samuel and Fuller 1994) fitted with a Garmin georeferencing instrument, performing simultaneous readings. We used a Suunto KB-14 (Finland) compass to obtain the directions for each triangulation.

Estimated Home Range. To obtain the location of each female deer, degrees were transformed to UTM coordiates for each triangulation using the software Tripoly 2 (Laundré 1990), considering a magnetic deviation of $9.15^{\circ}$ and an error of $0.7 \mathrm{ha}$. The home-range size of each individual deer female was estimated with the CALHOME Program (California Home Range; Kie et al. 1994) using a 95\% minimum convex polygon model (White and Garrot, 1990). A total of 1,317 locations were recorded (581 in 1997 and 736 in 1998). The number of locations used to calculate the home range was similar for each individual female in the two years (Table 1).

To perform the analysis, the breeding season was divided into four stages regardless of the female reproductive status: 1) pre-breeding stage (April to June), corresponding to the late gestation period. 2) First breeding stage (July), when fawns are completely dependent on the mother. 3) 
Second breeding stage (August), when fawns start becoming independent. 4) Third breeding stage (October), corresponding to the total weaning of fawns. The results were analyzed at two levels: a) variations in each breeding stage considering the home range of the eight females captured, and b) variations in each stage at the individual level, considering only three of the four females monitored in 1997 (with fawns) and 1998 (without fawns). The fourth female was excluded from the analysis because no records of its activity were noted during April (1997) and June (1998).

The data were not normally distributed, nor the variances were homogeneous, so that non-parametric analyzes were used (Zar 1996). The variations in home-range size was explored for each stage at the sample level $(n=8)$ between females with and without fawns using Kruskal-Wallis and Mann-Whitney tests (Zar 1996). The monthly home-range size at the individual level for the three females monitored during the two years was analyzed using Friedman tests. The home-range size of females with and without fawns was compared using Wilcoxon tests (Zar 1996).

Use of and Preference for Plant Associations. Only the three females that were observed with and without fawns were considered. An analysis was made throughout the entire breeding season and another for each breeding stage, considering the availability of each plant association in both Rancho San Francisco and the home range of each female. We used the ArcView geographic information system software to obtain a digitized map of the home range of each female, derived from the locations recorded through radio telemetry for each plant association. The habitat use and preference were derived for each female from the number of locations in each plant association. The use of associations according to availability was assessed with $X^{2}$ tests (Zar 1996) and Bonferroni intervals (Byers et al. 1984).

\section{Results}

Home Range. Home-range size varied between females with and without fawn across the stages analyzed $(\mathrm{H}=$ $16.84, P=0.01$ ). In females with fawns, it was largest in the pre-breeding and second-breeding stages $(U=2, P=$ $0.05 ; U=1.0, P=0.01$, respectively). The home-range size between stages was similar in females with fawns $(H=4, P$ $=0.20)$. Females without fawns $(H=9, P=0.02)$ showed a smaller home range from the pre-breeding stage to the first and second breeding stages (Figure 1).

At the individual level, the three females monitored in 1997 versus 1998 showed a similar home-range size across stages. However, there was a trend to display larger homerange sizes when raising fawns and in the pre-breeding stage, that did not reach statistical significance $\left(n=3 ; X^{2}\right.$ $=12, P>0.05)$. A similar size across stages was observed in both females with fawns $\left(\mathrm{Xr}^{2}=5, P>0.05\right)$ and females without fawns $\left(\mathrm{Xr}^{2}=7, P>0.05\right)$. These females relocated their home range in each stage, showing a different overlap between each breeding stage (Figure 2).
Figure 1. Home range of females with and without fawns of Texan white-tailed deer during the breeding season.

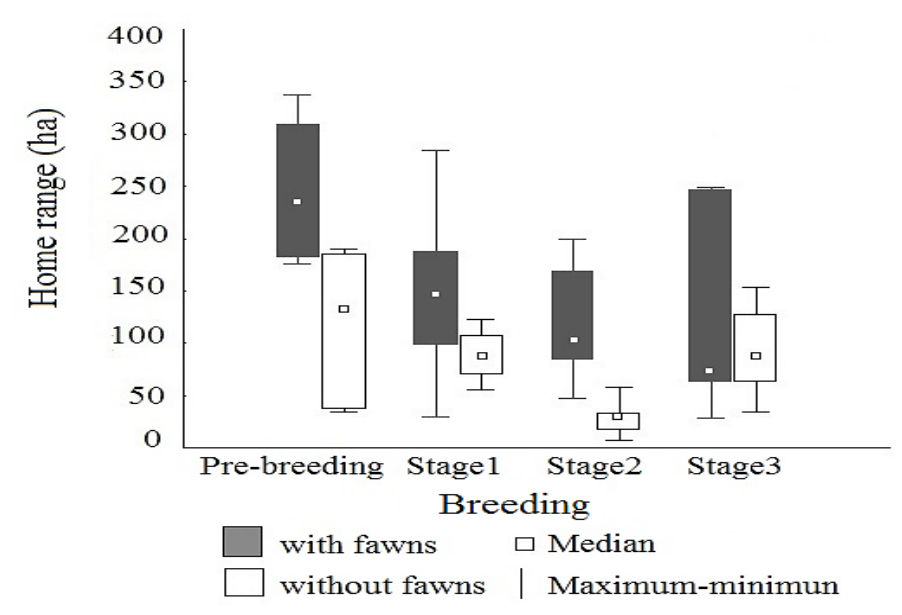

Use of and Preference for Plant Associations. Irrespective of their reproductive status, females included six of the seven plant associations in Rancho San Francisco within their areas of activity: Acacia-Prosopis, Leucophyllum frutescens, Prosopis, Acacia-Celtis, Flourensia cernua and Hilaria mutica (Figure 2). The number of observations corresponding to each plant association differed for each of the females, within an interval that ranged from 0 locations in Opuntia up to 91 locations in Acacia-Prosopis (Figure 3).

During each breeding stage, females displayed a differential use of the plant associations. females with fawns (female 1: $X^{2}=16$, d. f. $=8, P=0.001$; female $2: X^{2}=33$, d. f. $=8, P=0.001$; female $3: X^{2}=41$, d. f. $=10, P=0.001$ ) and without fawns (female $1: X^{2}=30$, d. f. $=10, P=0.001$; female 2: $X^{2}=37$, d. f. $=10, P=0.001$; female 3: $X^{2}=37$, d. f. $=10, P=0.001)$. The proportion of home-range use differed between stages and females showed a preference

Figure 2. Location of the home range of females of Texan white-tailed deer with and without fawns during the breeding season. Plant associations: Acacia-Prosopis (1); Prosopis (2); Leucophyllum (3); Acacia-Celtis (4); Flourensia (5); Hilaria (6); Opuntia (7).
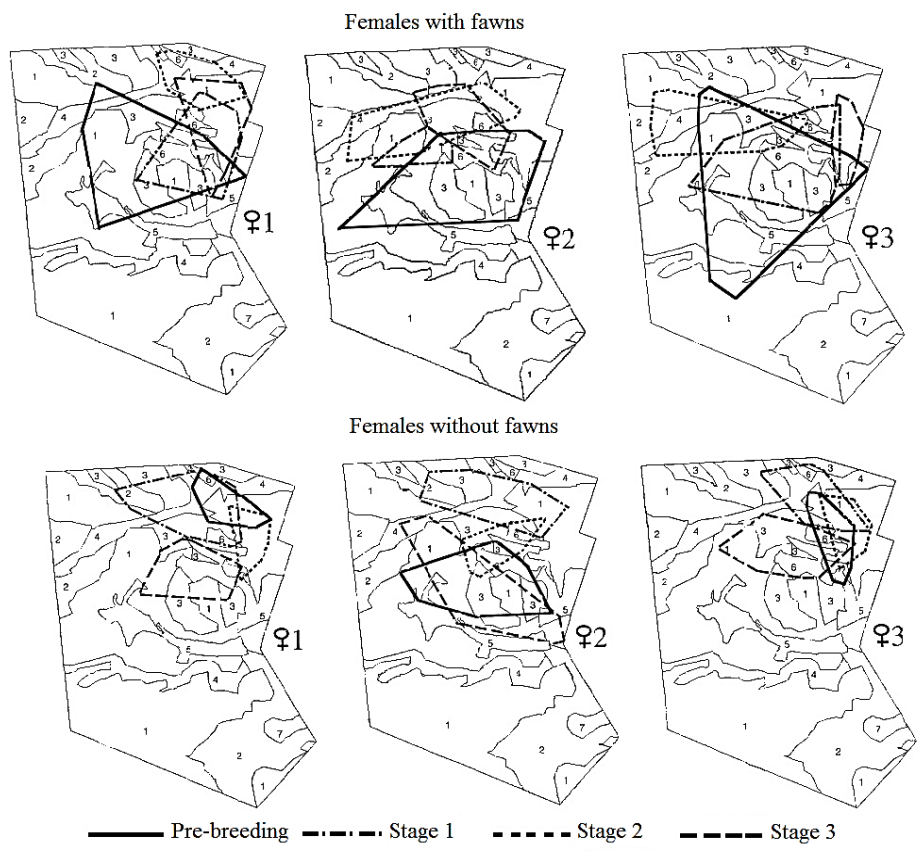

Females without fawns
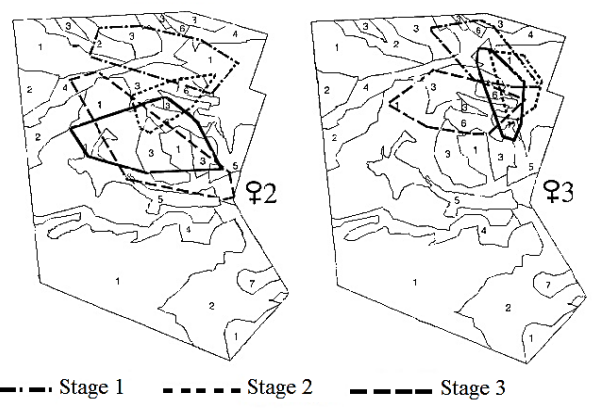
for Acacia-Prosopis only (Figure 3). No difference was found in the behavior of females with and without fawns in the three breeding stages (Females 1,2 and $3 ; P<0.03$ ).

Figure 3. Use of and preference for plant associations by females in each breeding stage: $\mathrm{w} / \mathrm{f}$ with fawns and $\mathrm{w} /$ of without fawns. Symbols: greater-than expected use (+); lower-than-expected use (-); expected use (unsigned); association not included in the home range ( $\mathrm{Ni})$.
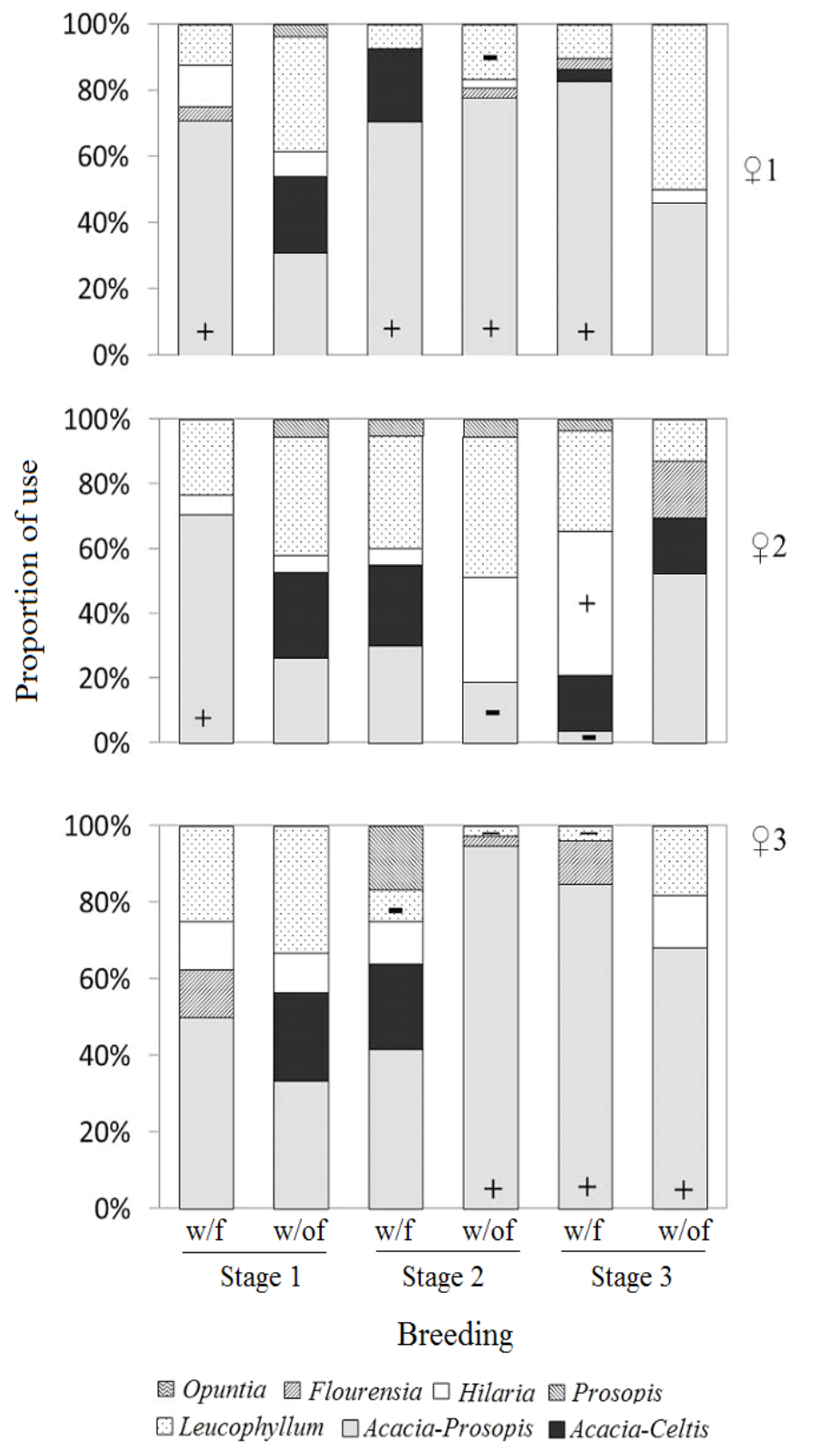

\section{Discussion}

Females with fawns showed larger home ranges in the prebreeding and the second breeding stages, which is consistent with the report by Bertrand and collaborators (1996). This may be due to the increased energy metabolism in the last gestation stage (30 to 45\%) rather than in lactation (Gallina and Bello 2010). In Rancho San Francisco during the breeding season, females increase their energy expenditure to $100 \mathrm{Kcal} /$ ind/day (Gallina and Bello 2010), as well as the time dedicated to food search and feeding to consume herbaceous and shrub sprouts (Gallina et al. 1998). By contrast, the lack of fawns may foster optimal resource use within smaller areas, as females restrict their activity sites (Shipley and Spalinger 1995). Females with and without fawns relocated their home range in each breeding stage, which is common in deer, according to resource distribution and abundance, as well as social factors (Mackie 1970; Riley and Dood 1984; Tierson et al. 1985).

Females with fawns do not show a significant change in home-range size between pre-breeding and the three breeding stages, as reported in other studies (Zultowsky 1992; Beltrand et al. 1996). As reproduction was successful, all females seemingly obtained the resources needed simply by relocating their home ranges. The area used is likely the minimum area that allows them to obtain the resources needed to meet their energy demands and those of fawns in each breeding stage.

The most important plant associations for females during the breeding season are Acacia-Prosopis and Leucophyllum frutescens. These associations show an intermediate cover (39.5\% and $34 \%$ respectively), and a near-to-highest species richness (10 sp), surpassed only by Flourensia cernua (11 sp). Acacia-Prosopis showed an intermediate proportion of species consumed by deer (64.7\%), while Leucophyllum frutescens had the lowest percentage of such species ( 28.4\%; Bello et al. 2003). Therefore, habitat selection by females is seemingly determined by an intermediate cover value coupled with a high diversity of plant species.

Females use areas of intermediate plant cover during the breeding season, maybe as an anti-predator strategy. This cover allows fawns to hide in the vegetation while still facilitating a quick escape (Nelson and Mech 1981; Kie and White 1985; Schwede et al. 1994; Bowyer et al. 1998; Mandujano et al. 2004; DeYoung and Miller 2011); in addition, fawns obtain protection from high sun radiation and rainfall (Messier and Barrett 1985; Illius and Gordon 1987; Fox and Krausman 1994; Bowyer et al. 1998).

Nursing females apparently carried out an optimal foraging strategy, as observed in other sites (Marchinton and Hirth 1984; Hofmann 1989). They choose plant associations with high species diversity (Arceo et al. 2004), seeking food quality rather than abundance (Weckerly and Kennedy 1992; Weckerly 1994; Main et al. 1996; Kammermeyer and Larry 1997; Gallina et al. 1998), and inhabit areas with low food biomass if these increase the safety of their offspring against predation (Miquelle et al. 1992).

\section{Acknowledgments}

Logistical support was provided by DUMAC. The Consejo Nacional de Ciencia y Tecnología (CONACYT) provided financial support under Project No. 225260-5-2480BP. The U.S. Fish and Wildlife Service awarded a Master's degree scholarship to the first author. The Master's Degree in Wildlife Management was part of the Latin American Partnership of Training in Wildlife Management. The support provided by the U.S. Fish and Wildlife Service supplements 
of Conservation for the Protection of Nature. María Elena Sánchez-Salazar translated the manuscript into English.

\section{Literature cited}

Arceo, G. S. Mandujano, S., and L. A. Perez-Jimenez. 2005. Diversity of diet of white-tailed deer in a Mexican tropical forest. Mammalia 69:159-168.

Bahnak, B. R., J. C. Holland, L. J. Verme, and J. Ozoga. 1979. Seasonal and nutritional effects on serum nitrogen constituents in white-tailed deer. Journal of Wildlife Management 43:454-467.

Bello, J., S. Gallina, And M. Equihua. 2001a. Characterization and habitat preferences by white-tailed deer in Mexico. Journal of Range Management 54:537-545.

Bello, J., S. Gallina, M. Equihua, S. Mandujano, and C. Delfín- Alfonso. $2001 \mathrm{~b}$. Home range, core area and distance to water sources by white tailed deer in northeastern Mexico. Vida Silvestre Neotropical 10:30-37.

Bello, J., S. Gallina, And M. Equinua. 2003. El venado cola blanca: uso del hábitat en zonas semiáridas y con alta disponibilidad de agua del Noreste de México. Pp. 67-76 in Manejo de Fauna Silvestre en Amazonía y Latinoamérica-Criterios de Sostenibilidad (Polanco-Ochoa, R., ed.). CITES, Fundación Natura. Bogotá, Colombia.

Bello, J., S. Gallina, and M. Equinua. 2004. Movements of white tailed deer and their relationship with precipitation in the northeastern of Mexico. Interciencia 29:357-361.

Bello, J., S. Gallina, and M. Equihua. 2006. Distancias de desplazamiento del venado cola blanca y su relación con factores ambientales en el Noreste de México. Memorias VI Congreso en Manejo de Fauna silvestre en Amazonia y Latinoamérica:137-142

Beltrand, M., A. J. DeNicola, S. R. Beissinger, and R. K. Swihart. 1996. Effects of parturition on home ranges and social affiliations of female white-tailed deer. Journal of Wildlife Management 60:899-909.

Bongl, P., S. Ciutis, S. Grignolio, M. Del Frate, S. Simi, and D. Gandelli AND M. Apollonio. 2008. Anti-predator behavior, space use and habitat selection in female roe deer during the fawning season in a wolf area. Journal of Zoology 276:242-251.

Bowyer, R. T., J. G. KIE, AND V.Ballenberghe. 1998. Habitat selection by neonatal black-tailed deer: climate, forage, or risk of predation? Journal of Mammalogy 79:415-425.

BRIONES, V. O. 1984. Sinecología and florística de Lampazos de Naranjo, Nuevo León (México) con énfasis en la Gran Llanura. Tesis de Licenciatura. Universidad Autónoma de Nuevo León, México.

Byers, C. R, R. K. Steinhorst, and P. R. Krausman. 1984. Clarification of the technique for analysis of utilization-availability data. Journal of Wildlife Management 48:1050-1053.

Cook, R. S., M. White, D. O. Trainer, and W. C. Glazner. 1971. Mortality of young white-tailed deer fawns in South Texas. Journal of Wildlife Management 35:47-56.

DeYoung, R. W., AND K. V. Miller. 2011. White-tailed deer behavior. D. G. Hewitt. Biology and Management of White-tailed Deer. CRC Press. Boca Raton. Florida, U. S. A.

Fox, K. B., And P. R. Krausman. 1994. Fawning habitat of desert mule deer. The Southwestern Naturalist 39:269-275.
GaLlinA, S. 1981. Biology and population dynamics of Whitetailed deer in northwestern Mexico. Pp. 79-108 in Deer Biology, Habitat Requirements and Management in Western North America (Ffolliott, P. F., and S. Gallina, eds.). Instituto de Ecología. Ciudad de México, México.

Gallina, S., A. Pérez-Arteaga, and S. Mandujano. 1998. Patrones de actividad del venado de cola blanca (Odocoileus virginianus texanus) en un matorra1 xerófilo de México. Boletín de la Sociedad de Biología, Concepción, Chile 69:221-228.

Gallina, S., P. Corona, And J. Bello. 2003. El venado cola blanca: comportamiento en zonas semiáridas del Noreste de México. Pp. 165-173 in Manejo de Fauna silvestre en Amazonía y Latinoamérica-Criterios de Sostenibilidad (Polanco-Ochoa, R., ed.). CITES, Fundación Natura. Bogotá, Colombia.

Gallina, S., AND J. Bello. 2010. El gasto energético del venado cola blanca (Odocoileus virginianus texanus) en relación a la precipitación en una zona semiárida de México. Therya 1:9-22. Gallina, S., y J. Bello. 2014. Patrones de actividad del venado cola blanca en el noreste de México. Therya 5:423-436.

Gilliam, F. H., And D. F. Fraser. 1987. Habitat selection under predation hazard: test of a model with foraging minnows. Ecology 68:1856-1862.

Gilliam, F. H., and D. F. Frazer. 1989. Strong effects of foraging minnows on a stream benthic invertebrate community. Ecology 70:445-452

Gittlemann, J. L., and P. H. Harvey. 1982. Carnivore home-range size, metabolic needs and ecology. Behavioral Ecology and Sociobiology 10:57.63.

Green L. M., A. C. Kelly, D. Satterthwait-Phillips, M. B. Manjerovic, P. Shelton, J. NovakofSKI, AND N. Matheus-Pinilla. 2017. Reproductive characteristics of female while-tailed deer (Odocoileus virginianus) in the Midwestern USA. Theriogenology 94:71-78.

HaLL, R. 1981. The mammals of North America. Vol. I. John Wiley \& Sons. New York, U. S. A.

Holzenbein, S., And G. Schwede. 1989. Activity and movements of female white-tailed deer during the rut. Journal of Wildlife Management 53:219-223.

Hofmann, R. R. 1989. Evolutionary steps of ecophysiological adaptation and diversification of rumiants: a comparative view of their digestive system. Oecología 78:443-457.

Illius, A. W., AND I. J. Gordon. 1987. The Allometry of food intake in grazing ruminants. Journal of Animal Ecology 56:989-999.

KIE, J. G., AND M. WHITE. 1985. Population dynamics of whitetailed deer on the Welder Wildlife Refuge, Texas. The Southwest Naturalist 30:105-118.

KiE, J. G., J. A. BALdwin, And C. J. Evans. 1994. CALHOME home range analysis program electronic user's. U. S. Forest Service, Pacific Southwest Research Station. Albany, U. S. A.

Kammermeyer, K. E., ANd R. Larry. 1997. Seasonal change in circadian activity of radio-monitored deer. Journal of Wildlife Management 41:315-317.

LAUNDRÉ, J. W. 1990. Tripoly. Intermountain Wildlife Research Institute. University of Idaho. Idaho, U. S. A.

López-Soto, J. H. And M. H. Badı. 2000. Depredación en crías de venado cola blanca (Odocoileus virginianus texanus) por coyote (Canis latrans) en una Unidad de Manejo y 
Aprovechamiento del norte de Nuevo León, México. Acta Zoológica Mexicana (n. s.) 81:135-138.

Mandujano, S., S. Gallina, G. Arceo and L. A. Pérez-Jiménez. 2004. Variación estacional del uso y preferencia de los tipos vegetacionales por el venado cola blanca en un bosque tropical de Jalisco. Acta Zoológica Mexicana (n. s.) 20:45-67.

MACKIE, R. J. 1970. Range ecology and relations of mule deer, elk and cattle in the Missouri River Breaks, Montana. Wildlife Monographs 20:1-79.

Main, M. B., AND B. E. Coblentz. 1990. Sexual segregation among ungulates: a critique. Wildlife Society Bulletin 18:204-210.

Main, M. B., F. W. Weckerly, and V. C. Bleich. 1996. Sexual segregation in ungulates: new directions for researches. Journal of Mammalogy 77:449-461.

MarChinton, R. L., AND D. H. HIRTH. 1984. Behavior. Pp. 129-168 in White-tailed deer ecology and management (Halls, L. K. ed.). Stackpole Books. Pennsylvania, U. S. A.

MESSIER, F., AND C. BARRETTE. 1985. The efficiency of yarding behavior by white-tailed deer as an antipredator strategy. Canadian Journal of Zoology 63:785-789.

Miquelle, D. G., J. M. Peek, and V. Van Ballenberghe. 1992. Sexual segregation in Alaskan moose. Wildlife Monographs 122:1-57.

Nelson, M. E., AND L. D. MeCH. 1981. Deer social organization and wolf predation in northeastern Minnesota. Wildlife Monography 77:1-53.

Nixon, C. M., L. P. Hansen, P. A. Brewer, and E. Chelsvig. 1992. Stability of white-tailed doe parturition ranges on a refuge in east central Illinois. Canadian Journal of Zoology 70:968-973.

Ozoga, J. J., L. J. Venne, AND C. S. Bienz. 1982. Parturition behavior and territoriality in white-tailed deer: impacts on neonatal mortality. Journal of Wildlife Management 46:1-11.

KIE, J. G., AND M. WHITE. 1985. Population dynamics of whitetailed deer on the Welder Wildlife Refuge, Texas. The Southwestern Naturalist 30:105-118.

RILEY, S. D., AND A. R. Dood. 1984. Summer movements, home range, habitat use, and behavior of mule deer fawns. The Journal of Wildlife Management 48:1302-1310.

Samuel, D. M., and M. R. Fuller. 1994. Wildlife Radiotelemetry in Research and Management Techniques for Wildlife and Habitats (A. Bookhout, ed.). The Wildlife Society. Maryland, U. S. A.

SMIтH W. P. 1991. Odocoileus virginianus. Mammalian Species 388:1-3.

Schwede G., H. Hendrichs, and W. McShea. 1993. Social and spatial organization of female white tailed deer, Odocoileus virginianus, during the fawning season. Animal Behavior 45:1007-1017.

Schwede, G., H. Hendrichs, and C. Wemmer. 1994. Early motheryoung relations in white-tailed deer. Journal of Mammalogy 75:438-445.

Shipley, L. A., And D. E. Spalinger. 1995. Influence of size and density of browse patches on intake rates and foraging decisions of young moose and white-tailed deer. Oecología 104:112-121.

Tierson, W. C., G. F. Mattfield, R. W. Sage and D. R. Behrend. 1985. Seasonal movements and home ranges of white-tailed deer in the Adirondacks. Journal of Wildlife Management 49:760-769.

Villarreal, J. G. 2013. Ganadería diversificada: importancia ecológica, cinegética y económica de los venados mexicanos. SEGARPA. Monterrey, México.
Wallace, M. C., and P. R. Krausman. 1990. Neonatal elk habitat in central Arizona. Pp. 69-75 in The biology of deer (R. D. Brown, ed.). New York, U. S. A.

WECKERLY, F.W. 1994. Selective feeding by black-tailed deer: forage quality or abundance? Journal of Mammalogy 75:905-913.

WeCKERLY, F. W., AND M. L. KenNedy. 1992. Examining hypotheses about feeding strategies of white-tailed deer. Canadian Journal of Zoology 70:432-439.

White, G. C., And R. A. Garrot. 1990. Analysis of wildlife radiotracking data. Academic Press, Inc. California, U. S. A.

$Z_{A R}$, J. H. 1996. Biostatistical Analysis. Second Edition. Prentice-Hall. New Jersey, U. S. A.

ZuLTowsky, J. M. 1992. Behavioral and spatial ecology of female white tailed deer in the everglades ecosystem. Master of Science Thesis. Department of Wildlife and Range Sciences. University of Florida. Florida, USA.

Associated editor: Rafael Reyna

Submitted: Junio 21, 2017; Reviewed: Octuber 6, 2017;

Accepted: November 10, 2017; Published on line:December 23, 2017. 